\title{
Macromolecular materials in heterogeneous catalysis: an aluminium silasesquioxane gel as active catalyst in Diels-Alder reactions of enones
}

\section{Citation for published version (APA):}

Abbenhuis, H. C. L., Herwijnen, van, H. W. G., \& Santen, van, R. A. (1996). Macromolecular materials in heterogeneous catalysis: an aluminium silasesquioxane gel as active catalyst in Diels-Alder reactions of enones. Chemical Communications, ChemComm, 1996(16), 1941-1942. https://doi.org/10.1039/cc9960001941

DOI:

10.1039/cc9960001941

Document status and date:

Published: 01/01/1996

Document Version:

Publisher's PDF, also known as Version of Record (includes final page, issue and volume numbers)

\section{Please check the document version of this publication:}

- A submitted manuscript is the version of the article upon submission and before peer-review. There can be important differences between the submitted version and the official published version of record. People interested in the research are advised to contact the author for the final version of the publication, or visit the DOI to the publisher's website.

- The final author version and the galley proof are versions of the publication after peer review.

- The final published version features the final layout of the paper including the volume, issue and page numbers.

Link to publication

\footnotetext{
General rights

- You may freely distribute the URL identifying the publication in the public portal. follow below link for the End User Agreement:

www.tue.nl/taverne

\section{Take down policy}

If you believe that this document breaches copyright please contact us at:

openaccess@tue.nl

providing details and we will investigate your claim.
}

Copyright and moral rights for the publications made accessible in the public portal are retained by the authors and/or other copyright owners and it is a condition of accessing publications that users recognise and abide by the legal requirements associated with these rights.

- Users may download and print one copy of any publication from the public portal for the purpose of private study or research.

- You may not further distribute the material or use it for any profit-making activity or commercial gain

If the publication is distributed under the terms of Article 25fa of the Dutch Copyright Act, indicated by the "Taverne" license above, please 


\title{
Macromolecular materials in heterogeneous catalysis: an aluminium silasesquioxane gel as active catalyst in Diels-Alder reactions of enones
}

\author{
Hendrikus C. L. Abbenhuis, Hendrikus W. G. van Herwijnen and Rutger A. van Santen* \\ Schuit Institute of Catalysis, Eindhoven University of Technology, PO Box 513, 5600 MB Eindhoven, The Netherlands
}

\begin{abstract}
A highly active, genuinely heterogeneous catalyst for liquid-phase Diels-Alder reactions of enones results from the silanol centred modification of an incompletely condensed silasesquioxane with trimethylaluminium, the resulting catalytic material being a gel that contains aluminium(II) siloxy functions (Al-O-Si) which are incorporated in a well defined, three-dimensional $\mathrm{SiO}$ framework.
\end{abstract}

At present, silasesquioxane metal complexes can be considered as the best chemical models for a variety of silica supported metal catalysts. ${ }^{1}$ In addition, porous materials have recently been synthesized from silasesquioxane cage precursors, ${ }^{2}$ as well as metal-containing polymeric derivatives. ${ }^{3}$ As such, this field has matured to the extent where applications to heterogeneous catalysis may become feasible. Here we report on the formation of an inorganic gel from a silasesquioxane and an organoaluminium precursor. The resulting gel is a highly active, heterogeneous catalyst for liquid-phase Diels-Alder reactions of enones. This paper, therefore, expands the scope of silasesquioxane chemistry to the area of heterogeneous catalysis.

The silasesquioxane 1 (Fig. 1) provides an useful bifunctional building-block for the construction of organosilicious polymeric materials. In 1, two hydroxy groups occupy 'exo' positions above interconnected $\mathrm{Si}_{4} \mathrm{O}_{4}$ rings, which are part of a three-dimensional $\mathrm{Si}_{8} \mathrm{O}_{11}$ skeleton. Because of the spatial restrictions of the silasesquioxane skeleton, silanol centred reactions of 1 with bi- and multi-functional organometallics are likely to give polymeric complexes through formation of bridging metal siloxy units. Recently, functionalisations of 1 have been reported that proceed via clean silanol centred reactions and that leave the silasesquioxane skeleton intact. $4-6$

We found that, in toluene, the silanol groups present in $\mathbf{1}$ easily react with trimethylaluminium (Scheme 1 ), resulting in concomitant formation of methane and a colourless aluminosilasesquioxane gel 2 that occludes the entire volume of the solvent used ( $c a .50 \mathrm{ml} \mathrm{g}^{-1}$ ). Upon drying in vacuo, the gel collapses into a powder, losing all solvent. The swelling capacity of the dried aluminosilasesquioxane gel 2 for toluene is reduced to approximately $0.5 \mathrm{ml} \mathrm{g}^{-1}$.

When the aluminosilasesquioxane gel 2 is subjected to hydrolysis followed by organic work-up, the silasesquioxane 1
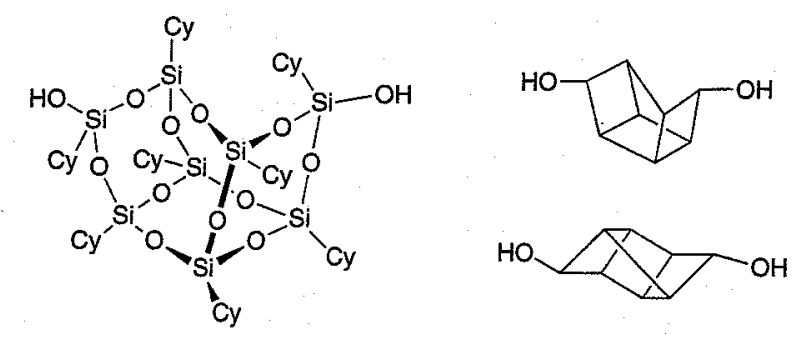

Fig. 1 Structure of the silasesquioxane building block 1 (left) together with schematic representations (right) of the silasesquioxane skeleton, the :orners represent cyclohexylsilicon units, the connecting lines represent rridging oxygen atoms; $\mathrm{Cy}=\mathrm{C}_{6} \mathrm{H}_{11}$ can be recovered in near to quantitative yield (Scheme 1). From this finding, it can be concluded that gel 2 contains a silasesquioxane cage framework similar to that present in the precursor $\mathbf{1}$.

Analysis of the aluminosilasesquioxane gel 2 by single pulse $79.5 \mathrm{MHz}{ }^{29} \mathrm{Si}$ MAS NMR provides a method to establish the degree of silanol functionalisation. Upon substitution, the originally lower field resonance of the silanol silicon atoms at $\delta$ -58.9 shifts towards the higher field part of the spectrum where the other silasesquioxane silicon resonances are also found $(\delta$ -65 to -75 ). Comparison of the integrals over the two distinct parts of the spectra indicates that the fraction of remaining silanol units in the aluminosilasesquioxane gel 2 is $<0.05$ (cf. 0.25 in the silasesquioxane 1), i.e. $>80 \%$ of the silanol units of the starting material 1 have been functionalised in the gel forming process. The 104.2 $\mathrm{MHz}^{27} \mathrm{Al}$ MAS NMR spectrum of 2 consists of three, partially resolved resonances at $\delta 50.0,29.9$, and $-1.7\left(w_{1 / 2} \approx 2500 \mathrm{~Hz}\right)$, characteristic of respectively four, five, and six-coordinate aluminum siloxy units. ${ }^{7}$

The aluminosilasesquioxane gel 2 can be considered as a polymeric Lewis acid. Therefore, we have tested gel 2 as a catalyst for Diels-Alder reactions of enones (Scheme 2). Using 2 , liquid-phase catalytic reactions were conducted in a glass batch reactor at $20^{\circ} \mathrm{C}$. In a typical reaction, $2.0 \mathrm{mmol}$ of diene and $2.0 \mathrm{mmol}$ of dienophile were reacted over the catalyst (1 $\mathrm{mol} \% \mathrm{Al}$ with respect to the substrates) in the presence of $\mathrm{CDCl}_{3}$ as solvent. Some of the results obtained are listed in Table 1 . The catalyst employed here accelerates Diels-Alder reactions by several orders of magnitude over the thermal reaction. Moreover, we found that the non-catalysed reactions proceed with formation of up to $30 \%$ of 3,4-dihydropyranes, resulting from homo-Diels-Alder reactions of the enones. When the catalyst is filtered off, which was repeatedly done when reactions had reached $c a$. $50 \%$ conversion, the reaction rate decreases to the thermal rate. From this finding, we conclude that 2 is a truly heterogeneous catalyst.

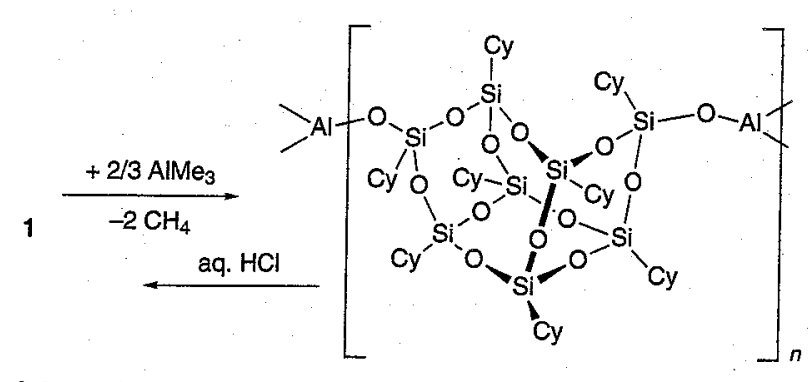

Scheme 1 Synthesis of the aluminosilasesquioxane gel 2; Cy $=\mathrm{C}_{6} \mathrm{H}_{11}$

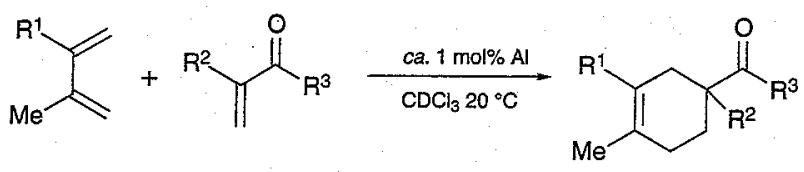

Scheme 2 
Compared to other Lewis-acidic catalysts useful for DielsAlder transformations, both homogeneous ${ }^{8}$ and heterogeneous, the aluminosilasesquioxane gel described here has, at least for the studied reactions, an activity and lifetime that is comparable to the best reported catalysts known to date. With regard to the heterogeneous catalysts, good results have been reported with silica and alumina supported Lewis acids, which are in some way related to the aluminosilasesquioxane described here. ${ }^{9-12}$ In addition, zeolites are also successfully employed in this field. ${ }^{13,14}$

In summary, it has been demonstrated that incompletely condensed silasesquioxanes are convenient building blocks for

Table 1 Diels-Alder reactions catalysed by the aluminosilasesquioxane gel $2^{a}$

\begin{tabular}{lllllll}
\hline $\mathrm{R}^{1}$ & $\mathrm{R}^{2}$ & $\mathrm{R}^{3}$ & $t^{b} / \mathrm{h}$ & $\begin{array}{l}\text { Isomer } \\
\text { ratio }^{c}\end{array}$ & $\begin{array}{l}k_{2} d / \\
1 \mathrm{~mol}^{-1} \mathrm{~h}^{-1}\end{array}$ & $k_{2} / k_{2 \text { (thermal) }}{ }^{2}$ \\
\hline $\mathrm{H}$ & $\mathrm{H}$ & $\mathrm{Me}$ & 4.5 & $88: 12^{e}$ & 0.30 & $6.1 \times 10^{2}$ \\
$\mathrm{Me}$ & $\mathrm{H}$ & $\mathrm{Me}$ & 4.5 & & 0.97 & $3.2 \times 10^{2}$ \\
$\mathrm{H}$ & $\mathrm{H}$ & $\mathrm{H}$ & 3.5 & $95: 5 f$ & 1.4 & $6.4 \times 10^{2}$ \\
$\mathrm{Me}$ & $\mathrm{H}$ & $\mathrm{H}$ & 1.5 & & 3.0 & $8.8 \times 10^{2}$ \\
$\mathrm{H}$ & $\mathrm{Me}$ & $\mathrm{H}$ & 20 & $91: 9 f$ & 0.22 & $2.5 \times 10^{3}$ \\
$\mathrm{Me}$ & $\mathrm{Me}$ & $\mathrm{H}$ & 10 & $\cdots$ & 0.4 & $2.1 \times 10^{3}$ \\
\hline
\end{tabular}

${ }^{a}$ Reactions were performed using equimolar amounts $(2.0 \mathrm{mmol})$ of diene and dienophile in $\mathrm{CDCl}_{3}$ at $2.0 \mathrm{~mol} \mathrm{dm}-3$ concentration at $20^{\circ} \mathrm{C}$ in sealed vials that were magnetically stirred using $34 \mathrm{mg}$ ( 1 mol\% Al) of catalyst 2 . Conversions and yields were determined by GC-MS and ${ }^{1} \mathrm{H}$ NMR using an internal standard (tert-butylbenzene). ${ }^{b}$ Time for $90 \%$ conversion. ${ }^{c}$ Ratio of 1,4- vs. 1,3-disubstituted cyclohexenes. ${ }^{d} k_{2}$ refers to the average reaction rate measurement. $e$ Thermal reactions proceed with formation of up to $30 \%$ of 3,4-dihydropyranes resulting from homo-Diels-Alder reactions of the enones. $f$ Isomer ratio of the thermal reaction is $71: 29 . g$ Isomer ratio of the thermal reaction is $75: 25$. the construction of aluminium containing gels. The resulting materials can be successfully employed as genuinely heterogeneous catalysts in liquid-phase reactions.

H. C. L. A. thanks the Royal Netherlands Academy of Arts and Sciences for a fellowship.

\section{References}

1 For a recent review see: F. J. Feher and T. A. Budzichowski, Polyhedron, 1995, 14, 3239.

2 P. G. Harrison and R. Kannengieser, Chem. Commun., 1996, 415.

3 T. S. Haddad and J. D. Lichtenhan, J. Inorg. Organomet. Polym., 1995 , $5,237$.

4 J. F. Walzer, D. A. Newman and F. J. Feher, J. Am. Chem. Soc., 1989 , 111, 1741.

5 F. J. Feher, T. A. Budzichowski, K. Rahimian and J. W. Ziller, J. Am Chem. Soc., 1992, 114, 3859 .

6 J. D. Lichtenhai, N. Q. Vu, J: A. Carter,J. W. Gilman and F. J. Feher Macromolecules, 1993, 26, 2141 .

7 G. Engelhardt and D. Michel; High-Resolution Solid-State NMR of Silicates and Zeolites, Wiley, Chichester, 1987, p. 186.

8 T. K. Hollis, N. P. Robinson and B. Bosnich, J. Am. Chem. Soc., 1992, 114, 5464 and references therein.

9 C. Cativiela, J. I. García, J. A. Mayoral, E. Pires, A. J. Royo and F. Figueras, Tetrahedron, 1995, 51, 1295.

10 G. Hondrogiannis, R. M. Pagni, G. W. Kabalka, R. Kurt and D. Cox, Tetrahedron Lett., 1991, 32, 2303.

11 C. Cativiela, J. M. Fraile, J. I. García, J. A. Mayoral, E. Pires, A. J. Royo and F. Figueras, Tetrahedron, 1995, 51, 1295.

12 C. Cativiela, J. M. Fraile, J. I. García, J. A. Mayoral, E. Pires, A. J. Royo; F. Figueras and L. C. de Ménorval, Tetrahedron, 1993, 49, 4073.

13 C. Cativiela, J. M. Fraile, J. I. García, J. A. Mayoral, J. M. Campelo, D. Luna and J. M. Marinas, Tetrahedron: Asymmetry, 1993, 4, 2507.

14 Y. V. S. Narayana Murthy and C. N. Pillai, Synth. Commun., 1991, 21, 783.

Received, 17th May 1996; Com. 6103442J 